\title{
Poverty of Traditional Fisherman Percut Village Percut Sei Tuan District Deli Serdang District
}

\author{
Bengkel Ginting \\ Social Welfare Department \\ University of Sumatera Utara \\ Medan, Indonesia \\ bengkelginting@ymail.com
}

\begin{abstract}
As an archipelagic country, Indonesia has the marine economy resources especially the abundant fishery resources. The potential has not been well managed, still small contribution of marine and fishery sector to national income, only $14.7 \%$ of total product broto domistik (PDB) Indonesia, compare with other countries, Japan only has $31.000 \mathrm{~km}$ coastline but contribute 55\% GDP .
\end{abstract}

The dramatic phenomenon between the potential and utilization of marine resources is directly proportional to the life of coastal communities who mostly work as fishermen. Some leteratur meyebutkan, fishermen are a group of poor people, even when compared with other agricultural groups in the agricultural sector, traditional fishermen can be included into the poorest group.

Using qualitative approach this study analysis factors which contributed to the presistence of poverty among traditional fisherman remained poor despite the abundance of natural resources and government's empowerment program.

The study demonstrates that the poverty of traditional fishermen is influenced by two factors: The first internal factors include: limited human resource quality, limited business capital and capture technology, difficulty of diversification of fishing, and a wasteful lifestyle that is less oriented toward the future. The two external factors include: fisheries development policies are more productivity oriented to support national economic growth and, fishery product marketing system is more profitable intermediary traders, toke, damage to coastal and marine ecosystems, the use of fishing equipment is not environmentally friendly, weak law enforcement against destructive environment, limited postharvest processing technology, limited job opportunities in non-fishery sector available in fishing village.

For that reason, the traditional fishermen empowerment program should be more successful if it starts from the realistic conditions that occur in their daily lives. Because, traditional fishermen not only poor material but also poor information. The combination of top down planning and bottom up planning will be more effective in empowerment programs.

\section{Keywords - Fishermen, Poverty and empowerment}

\section{INTRODUCTION}

Fishermen are a group of people whose lives depend directly on seafood, either by capture or cultivation. They generally live on the beach, a neighborhood close to the location of their activities. Imron in (Mulyadi, 2005: 7)

Geographically, the fishing communities live, grow and develop in coastal areas, a transition area between land and sea (Kusnadi, 2009). The potential of Indonesia's great marine and fishery resources in the world is very contradictory to the current reality where $98.7 \%$ of Indonesian fishermen belong to the category of small fishermen and $25.14 \%$ of Indonesia's poor are fishermen (Surono, 2015: 27).

The potential has not been well managed, it is marked by the still small contribution of marine and fishery sector to the national income that is only reach $14.7 \%$ from total product of broto domistik (PDB) Indonesia, compare with other countries like Japan, $31,000 \mathrm{~km}$ but accounted for $55 \%$ of GDP. In addition, according to Nugroho (2013: 14-15) the value of Indonesian exports from the marine and fisheries sector is still relatively small only reached 3.5 billion US dollars, compared with Vietnam and Thailand, each reaching 6.2 billion US dollars and 8, 6 billion US dollars even though their coastline is much smaller compared to Indonesia.

This dramatic phenomenon between the potential and utilization of marine resources is directly proportional to the life of coastal communities who mostly work as fishermen. Several leteratures (Mubyarto, 1984, Ginting, 19996, Imron, 2001, Masyhuri, 1999; Suprapto; 2012, Tahawila, 2014) mentioned that fishermen are a poor group, even by Retno and Santiasih as quoted by Imron (2003: 64) with other community groups in the agricultural sector, fishermen, especially fishermen and traditional fishermen, can be included in the poorest groups. Dense, slum, polluted residential neighborhoods, low incomes, and high vulnerability are generally attributed to their communities (traditional fishermen) in Indonesia.

The scenery that is often found in the fishing village is a shabby environment and houses are very simple. Even if there are some houses that show signs of prosperity (eg, grand houses and parabolic aisles), the houses are generally housewives, financiers, or loan sharks (Zainul, 2007: 36)

Fishermen communities are categorized as poor communities with indications that the economic level is still weak because of income levels, quality of life, low social welfare, and life in trouble. Fishermen are also caught in a 
trap of poverty, lacking adequate access to education and health. Fishermen also have difficulty getting access to credit as most banks assume that loans to fishermen are at high risk.

According to the data, the number of fishermen in North Sumatra around 321,000 people spread in 13 districts and cities, of which the number of traditional fishermen reached 70 percent, 20 percent medium-size fishermen and 10 percent of large fishermen. Means, marginalized fishermen are about 70 percent of the number of fishermen (about 224 thousand more) fishermen are still below the poverty line (BPS Sumut, 2009).

Deli Serdang Regency as one of the regencies in North Sumatera Province shows that the number of poor people from 2009 - 2010 has decreased. From 94,800 inhabitants $(5.7 \%)$ to $91,440(5.17 \%)$. Based on data from the Central Bureau of Statistics (2016) Deli Serdang Regency has an area of 4,339 km2. The livelihood of Deli Serdang residents also varies, such as fishermen, farmers / planters, civil servants, employers, laborers and so on (Central Bureau of Statistics 2016).

The life of a poor traditional fisherman community raises a sense of questioning due to the great potential of the sea and the location of the village close to Medan city. Besides, despite the empowerment programs of both the gear motorization and Coastal Economy Community Empowerment (PEMP) since 2001, the National Development Program Marine Fisheries Society (PNPM KP) has been done, it turns out that the lives of traditional fishing communities remain poor,customers do not go to sea or even go to sea just enough to pay the debt in the shop.

\section{RESUlTS AND DisCUSSIONS}

\section{A. Fish Auction System and Profitable Parties}

Fisherman's village in Percut Village is one of the coastal villages that produce fish, shrimp and shellfish. For marketing of fishermen's production, the government has constructed the fish auction facilities (TPI) and the auction conducted by KUD Mina under the supervision of the auction of fish auction (API).

Although there are fish auction facilities, but the implementation of the auction takes place with a controlled auction system. Any boat that docked at Fish Landing Center will be offered direct fish or toke. In the hamlet of the chart, besides TPI there is also a fish landing center (tangkahan) belonging to the toke. Tangkahan serves to serve fishermen who landed at night. Total production in the tangkahan is difficult to monitor, but because TPI does not work at night, the existence of toke shoots enough to help fishermen.

Based on information in the field, fish prices at TPI Percut most expensive compared to other TPI in North Sumatra. This privilege is partly due to the location of the village near Medan so that the condition of fish and shrimp are still fresh. In addition, the role of busy domestic tourists visiting makes the selling price of fish in TPI increased.
Traders sometimes let travelers trade with docked fishermen and then tourists handing fish or shrimp to a restaurant near TPI or taken to a floating restaurant located a mile from the TPI.

At the time of many tourists, fishermen have the opportunity to raise the selling price and by itself toke or the contractor must adjust to the circumstances and participate in raising the price. Fish, shrimp or shellfish collected by merchants and toke at the center of the landing, then arranged into baskets and delivered to toke subscriptions in the center of Medan market and large shrimp delivered to shrimp factory. There are also contractors who sell their own fish in the center of Medan market.

The presence of the traveler does have a positive impact on the seller, but the most benefited are toke or pemborong. "If the little result I may sell to tourists with high prices, but if many forced me to sell toke or contractor". Said a fisherman claimed he had to sell large shrimp to toke because he was bound by borrowing money and buying nets.

\section{B. Causes of Poverty}

According to Surono (2015) the poverty of fishermen is influenced by several factors. First low level of education. The low level of education is strongly influenced by their perception of education. For fishermen, education is not an essential need, because what is needed in the sea is skill and hard work, how to produce abundant catch and sold at high prices. Such skills will not be obtained at school, but derived from the learning process from the experience of going out to sea. This perception is still rooted in the fishing community of Percut Village. The picture is proven, from 10 research informants, five of them educated elementary school, four people with junior high education and only one person finish high school.

Research conducted by Mubyarto (2000) as quoted Siregar (2016) about the education of fishermen's children in the village of Bulu located on the edge of the city of Jepara, Central Java showed a similar thing. Mubyarto found the fact that the education of the fishermen's children is at the very low level the same as found in Percut Village.

This condition not only affects their ability to access technology and information, but also affects their ability to access other occupations in addition to work related to the sea especially during the famine (hurricane season). Occupations outside of sea work that can be accessed are construction workers or other work that is seasonal.

This low level of education causes traditional fishermen to become a very vulnerable group for exploitation. The results show that there is a very large margin between the catching of fishermen to toke with toke sales to retailers and consumers, both for local commodity catches, let alone export commodities. For the catch of the catch of local commodities such as margin can mencapi 7 - 15 thousand rupiah $/ \mathrm{kg}$, where fish purchased toke from fishermen only for $\mathrm{Rp} 18.000$ but at the consumer level the price can reach Rp 27.000 - Rp.35.000. For exports commodity more menyihatikan, Fish Krapu for example at the level of 
fishermen only in hargai of $\mathrm{Rp} 120,000 / \mathrm{kg}$, but the price changed to Rp. 400,000 when sold by toke to the exporter, and will reach Rp.800.000 / $\mathrm{kg}$ (62 \$ USA) at the consumer level abroad.

This exploitative problem when considering the reality that is in the village of Percut difficult to prevent because the level of dependence of fishermen to toke very large. There is a fundamental dependence of fishermen to the middlemen (toke)on the means of production. Informants still rely on toke's fishing gear, either by profit sharing or rental. Out of 10 research informants there were only three fishermen with their own fishing gear, with simple equipment and equipment (boats, fishing rods, nets, and outboard engines) or motor boats.

The fishing activities of the village of Percut still use traditional tools. With simple fishing gear, the operating area became limited, just around the coastal waters. In addition, the level of dependence on the season is very high, so not every can go to sea, especially in the waves season, which can be up to one month. Mahmud Sihotang, one of the informants in 16 villages, for example, said that they went down to the sea 12 to 16 times a month with the pattern of leaving the morning to come home during the day, or to go home early in the morning. As a result, in addition to the catch being limited, with the simplicity of fishing gear owned, in certain seasons there is no source of income. This condition resulted in the low income of fisherman which is only Rp.1.000.000 - Rp. 2,000,000 / month and the income earned during the fish season will be consumed during the famine.

Another problem faced by traditional fishermen in the sea is the competition of both traditional fishermen and modern fishermen. As it is known that marine resources are common property resources. Bailey (1998) discloses that the central problem of fisheries management in Indonesia is the absence of property rights limiting access to the resources. The free movement of people into fishing is possible because of the absence of property rights governing access to the resources. Fish is an open-access resource, freely available to anyone with the means to catch them. With this concept of ownership according to Imron (2003), marine resources are the object of unlimited competition, everyone will race to make as much fishing as possible, because if that is not done, the same resources will be captured by others. Therefore, in the field of fishery applies the principle of first come first own.

Kinseng (2014) argues that the socio-economic deprivation experienced by these small fishermen can theoretically radicalize another problem faced by traditional fishermen in the sea is the competition of both traditional fishermen and modern fishermen. Bailey (1998) discloses that the central problem of fisheries management in Indonesia is the absence of property rights limiting access to the resources. The free movement of people into fishing is possible because of the absence of property rights governing access to the resources. Fish is an open-access resource, freely available to anyone with the means to catch them. With this concept of ownership according to Imron (2003), marine resources are the object of unlimited competition, everyone will race to make as much fishing as possible, because if that is not done, the same resources will be captured by others. Therefore, in the field of fishery applies the principle of first come first own. That is, who comes first then he is the most likely to get more catches in that place. As a result of the seizure of resources that the fishermen with lower technology tend to lose in the competition.

Rifa'i (2015) says that with outboard motors or motor boats smaller than 20 GT fishermen can only catch the fish farthest 4 miles from the coastline, while the waters above 412 miles can only be reached by the above capacity vessels 30 GT. The number of nelayanya is not more than $19 \%$ of the total fishermen as a whole. This condition causes the fishing area about 4 miles from the coast to become a means of seizure by small fishermen, while the fishing area of 4 12 miles to the Exclusive Economic Zone is only controlled by a handful of large fishermen and fishery companies. Though the fishing area is very wide and has a much more abundant fish resources. Even more concerning the reality is the area or area 4 miles from the beach gari that should be a fishing area of small-traditional fishermen also participated by modern fishermen with sophisticated fishing equipment. Kebali quotes Bailey (1998) the birth of technology in the marine and fishery sector in Indonesia on one hand has provided great benefits to a small number of fishermen who have the capital, but on the other hand also gave birth to the battle of the zero sum game model where the minority group that has the most powerful technology controls the whole the available resources, and excluding other groups (the situation in fisheries is even worse than in agriculture because of the promotion of rapid technological change, fisheries development in Indonesia has become a zero-sum game, where those who control the most powerful technologies have a clear competitive advantage and individual prosper, even as the others are swept aside and fish stocks depleted). Rajali, one of the informants from hamlet 16, said that the presence of trawls of tigers, trawls, direct and indirect fishing trunks has caused their income (small fishermen) to be smaller, because these trawlers not only take fish with more they, but also damage the marine ecosystem, therefore they often do protests by burning the seines

Kinseng (2014) says that the socio-economic deprivation experienced by these small fishermen can theoretically elicit radicalism and social conflict. Betke (1988) argues that fishermen themselves trapped in a increasingly hopeles situation, Indonesian fishermen enventually rebelled an desperately counter - attacked the representative of a moderation of the treatped survival. Social conflicts are sometimes very berutal accompanied by trawling, physical fights, until the killing. For the case of North Sumatra, the trawling and fishing gear is not only happening in Percut, but it occurs almost in all areas of the east coast. In 2013, for example, 74 fishermen of Perlis Langkat village were arrested by the Langkat resort police for firing on trawlers, physical clashes that caused four trawling tigers and one fisherman died to extend to Langkat Mapolres area, on the owner of a trawler. Similar conflicts occur in the districts of 
Batubara, Tanjung Balai, Belawan, Labuhan Batu, and others.

This "stuffy" and hopeless "situation does not then make the Percut fisherman in particular the hamlet of silence, exactly as revealed by Deter Evis (1997) there is always a survival strategy held by marginalized groups. In the village of percut, because of low income and not at all time to go to sea, the fishermen do work-side work such as construction workers, mecari shells / crabs, and farming. Ucok Nasution one of the informants who came from hamlet XVIII said that in addition to looking for fish at sea, he also looking for shellfish. The job of looking for these shells he did in his spare time. From the job of looking for these shells, Ucuk Nasution earns about Rp. 60,000 / day. According to Ucok Nasution the pattern of looking for shellfish by finding the fish is almost the same, they are grouped $10-15$ persons by hiring a toke'sboat, all the proceeds will be shared equally to all members after deduction of boat and fuel rent.

From the study, it is known that the average income of the traditional fishermen in Percut village, both fish catch and other additional products are relatively small, reaching only Rp 1,000,000 - Rp. 2.200.000.dibandingkan with sectoral minimum wage Kabupaten (UMSK) Deli Serdang in 2017 which reached Rp.2.865.130. This income can be said to be far from sufficient, let alone to form investment savings which will then be used to increase the capacity of fishing gear, to meet all basic needs of life and livelihood: housing, education, and health, such income is inadequate.

This condition, according to Imron (2003), caused the fishermen to be in a permanent poverty cycle. Because the poor traditional fishermen can not improve the quality of fishing gear. Because of the simple catching tools, the catch is small and income. This low income makes it difficult for them to set aside money to buy fishing gear with a high level of exploitation.

This poverty pressure pushed the women (wife) of traditional fisher of Percut village to get involved in fulfilling family economic needs, from 10 informants interviewed all stated that their wives were involved in improving family economy by working as shell shellfish, processing law, salted fish processing, even among the wives who then plunge into female fishermen.

\section{CONCLUSIONS}

Based on the facts found in the field, illustrated that the people in Hamlet Bagan still live in poor condition. The ongoing poverty becomes more complex as it deals with the internal factors of fishermen and the pressure of resources. While the location of fishermen hamlet not far from the city of Medan causing the village to be part of the economy of the city with all its consequences.

In the context of urban village relations, the people of Bagan Hamlet experienced rapid changes due to improved urban village transportation path. Consequently, the development of Medan City in the suburbs (sub-urban areas) caused the emergence of a new phenomenon that is the transformation of urban villages affecting lifestyles and consumption patterns, while the purchasing power of the population has not increased.

In terms of housing, it is impressed that the state of the fisherman's settlement is no different from that of 20 years ago, except for some creative fishermen (initially fishermen and finally trading at TPI). This physical description shows the hint that the strategic advantage of the fishermen hamlet has not been able to be utilized by the fishing community. There is even a tendency of economic opportunities that appear more exploited by migrants and toke. While the lifestyle and consumption patterns of society increasingly permeate the public. As a result of unfit consumption patterns, fishermen are indebted to loan sharks (a new institution where new toke implements fishermen toke relationship is limited in production relationships, so that in other activities fishermen are not protected).

The entry of motorization programs in 1980, PEMP in 2001 and PNPM KP 2010 have not been able to improve the standard of living of traditional fishermen. The pattern of toke relationships with fishermen similar to the exploitative pattern of patron-client relationships is characterized by relief activities where toke only provide assistance to fishermen in the necessity of the cost of fishing as a bond for fishermen to sell the catch to toke.

The condition of traditional fishermen to date shows that boat ownership structure is dominated by toke. So the position of production and marketing activities only benefit toke. The pattern of relationship between exploitative toke and fisherman and the helplessness of the fishermen adjust to the development either because of the pressure of resources or the influence of city life will be very prone to cause conflicts and social problems in the future From the findings in the field of fishing life of Hamlet Bagan, can be given advice as the following:

To prevent development programs from being enjoyed by certain people, a direct approach should be made to poor fishermen's households, because in the community there is a strategic group (traders, toke, who are not domiciled as fishermen, but constantly directs the program does not disrupt their advantageous position in the production activity strata and marketing. Given in fishing communities there are still habits that rely solely on income from sea activities, it is advisable to develop a double income pattern .. Trained the potential of small groups of fishermen in savings and loans: save the fish season so that in the famine season, money lenders, formally banks can implement a running bank system (serving customers in cars such as mobile libraries), so that fishermen can save every day during fish and shrimp season and prevent excessive snacking pattern while in season of too bad ilit debt on moneylenders. This running bank system does not seem to be difficult because Hamlet Bagan has the geographical advantage of being close to Medan City and saving ability of fishermen in reliable fish season. 


\section{REFERENCES}

[1] Bailley.Conner. 1988. The Political Economy Of Marine Fisheries Development In Indonesia. Indonesia No.46 (Oct).Cornell Southeast Asia.Program.

[2] -------. 1993 Resource Dependency And Community Stability In Coastal

[3] Fishing Communities Of Southeast Asia. Indiana University Workshop on Political Theory and Policy Analysis.

[4] ------- 1991. Cummunity - Based Fisheris Management Institutions In Indonesia. Auburn University.

[5] Imron, Masyhuri, 2003. Poverty in Fishermen Society.Journal of Society and Culture Volume 5. 2003

[6] Indarti, Iin et al. 2013. Coastal Community Empowerment Methods through Institutional Strengthening in Coastal Areas of Semarang City. BENEFIT Journal of Management and Business. Volume 17, Number 1, June 2013,

[7] Djumiarti, Point. 2005. Poverty Reduction Strategy: Portrait of Development Success. "Dialogue" JIAKP, V ol. 2, No. 3, September 2005

[8] Mulyadi, 2005. Indonesia Marine Economy, Jakarta: PT. Raja Grafindo Indonesia

[9] Mubyartoi et al, 1984, Fishermen and Poverty, Study of Anthropology Economics in Two Villages, Rajawali, 1984.

[10] Mamentu, Michael, 2015. Implementation of Capture Fishermen's Empowerment Policy in Manado City (Study of Implementation of Mina Perdesaan Program of Rural Fishers Catch by Marine and Fishery Service of North Sulawesi Province). LPPM Journal of EkoSosBudKum Field. Volume 2 No. 2 Year 2015.

[11] Nugroho, Matheus. 2013. Empowerment of Poor Fisherman Community through Traditional Fish Processing Business: Study Development of Diversification of Traditional Fish Processing in Kecamatan Lekok Pasuruan Regency. Neptune Marine Journal, Vol. 19, No. 1, January 2013.

[12] Patopo Kusuma Dewi. 2015. National Program for Community Empowerment (PNPM) Mandiri Marine Fisheries. Disprotek Journal. Volume 6 July 2, 2015.

[13] Rici Tri Harpin Pranata and Arif Satria. 2015. Fisherman Adaptation Strategy Against Establishing Regional Water Conservation Area In South Misool, Raja Ampat KKPD. Journal.Sosek KP Policies Vol. 5 No. 2 Year 2015.

[14] Retnowati, Endang, 2011. Indonesian Fishermen In Structural Poverty Vortex (Social, Economic and Legal Perspective). Journal Perspectives.Volume XVI.3 Year 2011.

[15] Surono.Ono 2015. Fisherman Cooperative Resource Management of Capture Fisheries Based on Gotong Royong Economy. Wahana Semesta Intermedia.Jakarta.

[16] Sudarso. 2011. Structural Poverty Stress Traditional Fishermen Community

[17] Urban.Alhada fisip 11. web.unair.ac.id

[18] Tahawila, Amrin. 2014. Study of Poverty of Fisherman's Poverty in Baiya Sub-District Tawaeli Sub-district Palu City. e-Journal Catalogist, Volume 2 No. 7, July 2014

[19] Widjajanti, Kesi. 2011. Community Empowerment Model. Journal of Development Economics Volume 12, Number 1, June 2011.

[20] Zamzami, Lucky. 2011. Empowerment of Coastal Economy Economy in Nagari Ampiang Perak, West Sumatera. MIMBAR, Vol. XXVII, No. 1 (June 2011): 113-125.

[21] Zainul, Yuswar, 2007. The Potpourri of Maritime Economy Development, Jakarta: Trisakti University.

[22] Betke Friedhem. (1988). Finding themselves trapped in a increasingly hopeles situation, Indonesian fishermen enventually rebelled an desperately counter - attacked the representative of a moderation of the treatped their survival. Desert Bielefeld University.German

[23] Ginting, Workshop, Household Response Fishermen Against Economic and Welfare Programs at Fisherman Community of Desa Percut Sei Tuan Deli Serdang Regency, North Sumatra, Sociology Thesis Pedesaaan Bogor Agricultural University, 1996
[24] Kurnia R. Luki. Policy analysis Improvement of Fishermen's Welfare in Kepulauan Seribu District Administration.Desertation. Istitut Pertanian Bogor (IPB) .2005

[25] Michel Sipahelut. Analysis of Fishermen Community Empowerment in Tobelo Sub-district, North Halmahera Regency.Thesis.Institut Pertanian Bogor (IPB). 2010

[26] Sutomo. 2003. Evaluation of Coastal Economy Economic Empowerment Program of PEMP case study in Banggai district of Central Sulawesi. Thesis S2 IP

[27] Kusnadi, 2005. Understanding and Anatomy of Poverty of Fishermen: Opportunities and Strategies for the Control. Paper presented in the Seminar on Efforts to Formulate Joint Steps for Poverty Reduction of Fishermen, PRPPSE-DKP Ministry of Marine Affairs and Fisheries, Jakarta, August 24, 2005

[28] --------, 2010.The Fisherman's Culture. Presented at the 2010 CULTURAL CELEBRATION event, with the theme "Cultural Expression of Fishermen Community in North Coast of Java", organized by Balai Preservation History and Traditional Values, Ministry of Culture and Tourism, in Yogyakarta.

[29] --------, 2016. Scarcity of Fisheries Resources and Fisherman Poverty: Due to Penetration of Capitalism Or Cultural Practice. Proceedings of the National Marine Seminar.University of Trunojoyo Madura. 